but dangerous to the touch. It grows from 2 or 3 inches to 10 or 15 feet in height, and emits a disagreeable odour. Says a traveller: "Sometimes, while shooting turkeys in the scrub, I have entirely forgotten the stinging tree till I was warned of its close proximity by its smell, and have often found myself in a full forest of them. I was only once stung, and that very lightly. Its effects are curious. It leaves no mark, but the pain is maddening, and for months afterwards the part when touched is tender in rainy weather, or when it gets wet in washing, \&c. I have seen a man who treats ordinary pain lightly rolling on the ground in agony after being stung, and I have known a horse so completely mad after getting into a grove of the trees that he rushed open-mouthed at everyone who approached him, and had to be shot. Dogs when stung will rush about whining piteously, biting pieces from the affected parts." "Mr. N. E. Brown, of the Royal Gardens, Kew, made an interesting contribution (Gard. Chron., loc. cit., p. 567) of his personal experience concerning the virulent effect of the sting of this species in the palm-house at Kew.

Tokio, January 25 .

\section{The Sailing-Flight of Birds.}

Since Mr. F. W. Headley urges (February i6, p. 5ir) readers of NATURE to make observations on the flight of the albatross, possibly a few remarks may be of interest from one who, as a student of aërodynamical problems, has carefully watched such wonderful performances.

One point which has always struck me is that the albatross almost invariably flies in immense circles, ever varying in size and direction. Sometimes the bird will be high overhead, then, swooping down on a curve, will skim closely over the tops of the waves, then suddenly rising again will float away to perhaps half a mile off, gradually sweeping arcund, and perhaps again attaining a considerable elevation. It seems quite impossible to decide, from observation, whether the elevation is gained from uptending winds. Without doubt, the bird takes every advantage of each puff or eddy he can find, but he does not progress, as in Mr. Mallock's figure, steadily from wave to wave, rising and falling with the waves. Nor does he, so far as one can judge, invariably rise when facing the wind, and vice versa. That albatrosses, as well as other birds, seem always to soar in circles, may be due to the circumstances that, for instance, in following a ship, they have to circle round and round in order to keep near it, not being able to fly at such a slow speed as that of the ship (and therein is a hint to our cross-Channel aviators). So too vultures and eagles may soar around, not wishing to depart from the district which they are watching. But the question to which I have long wished for a reply is, "Can birds soar in a straight line?" I remember many years ago seeing, on the Nile, flocks of pelicans gliding along on outstretched wings. Now these birds were progressing up the river, performing actual journeys, but I cannot remember whether they were actually soaring in a straight line all the time.

I have frequently noted, what is patent to all, that in calms there is no true soaring; also I feel sure that there is no kind of motion of the wing such as Mr. Hearn suggests. One thing is certain, and that is that a soaring bird, especially the albatross, always progresses at great speed. Having once obtained the initial impulse. there is so very little head resistance offered to forward motion by the bird that the speed slackens but little. He progresses, as described by I.angley, in the manner of a skater skimming over thin ice, travelling so fast that the ice has not time to break.

Much of interest on this matter is to be found in the old annual reports of the Aëronautical Society. In that for the year 1868 there is an interesting discussion in which Mr. Young is quoted as saying that he had noticed "the hollow form of birds' wings; these were not planes: indeed, a little consideration would show that the curved surface is better than a true plane.... He concluded that the best means of flight is by a curved wing." A great deal has been said on this subject during the last few years, but how many have read these old, and often instructive, discussions?

B. BADEN-POWELl.
The Non-simultaneity and the generally Eastward Progression of Sudden Magnetic Storms.

Fact.

IT will be necessary, first, to my regret, to direct attention to some further errors in Dr. Krogness's communication in Nature, December 8, I9I0, p. I70, to which I made reply in the issue of January 5, p. 306. He questioned the correctness of our time of beginning of the disturbance, May 8, 1902, as recorded on the horizontal intensity curve at Potsdam, viz. I2h. om. Greenwich mean civil time, whereas his determination for the same station was $\mathrm{r}$ ih. $58 \mathrm{~m}$. In my reply, I stated (idem, p. 307) that Dr. Krogness must have made an error somewhere, for, upon repetition of our time scalings, based upon the data supplied us by the Potsdam Observatory, we got our identical result. I next wrote to the Potsdam Magnetic Observatory and requested that the time be scaled with all possible accuracy from the original magnetogram. Under date Potsdam, January 20, 1911 , Dr. Venske gives the time in question as $1 \mathrm{mh} .59 .7 \mathrm{~m}$., hence within $0.3 \mathrm{~m}$. of our time, but differing $\mathrm{I} \cdot \mathrm{zm}$. from that of Dr. Krogness.

Furthermore, in compliance with a circular request, I am receiving almost daily from observatories over the whole globe fresh data on the fifteen sudden disturbances, July 29, 1906, to September 25, 1909, first investigated by Mr. R. L. Faris for the five Coast and Geodetic Survey observatories. It will be recalled that Mr. Faris's data had furnished important testimony on the question as to the strict simultaneity of abruptly-beginning disturbances. Both Drs. Chree and Krogness have attempted to break down this testimony, but the data received thus far from other observatories are bearing out the conclusions previously drawn.

Table I. contains the time data for the very same dis-

TABLE I.-Greenwich Mean Civil Times of beginning of Disturbances in the United States and at Potsdam.

\begin{tabular}{|c|c|c|c|c|c|c|c|}
\hline \multirow{2}{*}{ No. } & \multirow{2}{*}{ Date } & \multirow{2}{*}{$\begin{array}{l}\text { United } \\
\text { States }\end{array}$} & \multicolumn{2}{|c|}{ Potsdam } & \multicolumn{2}{|c|}{$\mathrm{P}-\mathrm{U}$} & \multirow{2}{*}{$\begin{array}{c}\text { Direc- } \\
\text { tion }\end{array}$} \\
\hline & & & Krogness & Venske & $\mathrm{K}$ & $\mathrm{V}$ & \\
\hline \begin{tabular}{l|}
20 \\
24 \\
25 \\
28 \\
30 \\
31
\end{tabular} & $\mid \begin{array}{rr}\text { 1906, July } & 29 \\
\text { 1907, July } & \text { IO } \\
\text { Oct. } & \text { I3 } \\
\text { 1908, Sept. II } \\
\text { Sept. } 28 \\
\text { Sept. } 29\end{array}$ & $\begin{array}{|cc|}\text { h. } & \mathrm{m} . \\
\text { I9 } & 56 \cdot \mathrm{I} 2 \\
\mathrm{I} 4 & 22 \cdot 92 \\
7 & 42 \cdot 36 \\
7 & 20 \cdot 82 \\
\mathrm{8} & 42 \cdot 00 \\
\mathrm{I} & 3 \mathrm{r} \cdot 68\end{array}$ & $\begin{array}{l}\mathrm{m} . \\
57 \\
22 \cdot 5 \\
42 \cdot 5 \\
20 \cdot 3 \\
42 \\
31 \cdot 8\end{array}$ & $\begin{array}{l}\mathrm{m} . \\
56 \cdot 5 \\
23 \cdot 2 \\
43 \cdot 7 \\
20 \cdot 7 \\
42 \cdot 6 \\
32 \cdot 0\end{array}$ & $\begin{aligned} & \mathrm{m} . \\
&+0.88 \\
&-0.42 \\
&+0.14 \\
&-0.52 \\
& 0.00 \\
&+0.12\end{aligned}$ & $\begin{aligned} & \mathrm{m} . \\
&+0 \cdot 38 \\
&+0.28 \\
&+\mathrm{I} \cdot 34 \\
&-0.12 \\
&+0.60 \\
&+0.32\end{aligned}$ & $\begin{array}{l}\text { E. } \\
\text { E. } \\
\text { E. } \\
\text { W. } \\
\text { E. } \\
\text { E. }\end{array}$ \\
\hline & & $\begin{array}{l}\text { Algebraic } \\
\text { Numerical }\end{array}$ & $\begin{array}{l}\text { mean } \\
1,,\end{array}$ & & $\begin{array}{l}+0.03 \\
\pm 0.35\end{array}$ & $\begin{array}{l}+0.47 \\
\pm 0.51\end{array}$ & \\
\hline
\end{tabular}

turbances chosen by Dr. Krogness. Confining our attention to the horizontal intensity disturbance curves, just as he does, we have first the mean time of beginning as derived from the five Coast and Geodetic Survey observatories (Faris's data, the means being formed by Dr. Krogness; for the last disturbance the record at Sitka was missing, so that in the mean only four observatories are embraced). Next is given the times of beginning for the Potsdam Observatory, first as derived by Dr. Krogness and employed in his communication (idem, p. I7r), next as recently scaled by Dr. Venske at Potsdam, using the original magnetograms. Forming the differences $P$ (Potsdam), U (United States), it is seen that for the Krogness scalings there are three plus differences, two minus ones, and one zero, resulting in an algebraic mean of but $+0.03 \mathrm{~m}$. The case is, however, different for the next column, which depends upon the Venske, i.e. the original data of the Potsdam Observatory; there are now five plus differences and but one minus, the algebraic mean being $+0.47 \mathrm{~m}$. or $0.44 \mathrm{~m}$. higher than that of Dr. Krogness. These differences (P-U) are small quantities, to be sure, but the interesting point is that, in every instance, for the Venske figures they are in the same direction as determined by me from the five Coast and Geodetic Survey observatories alone, and as published in Terrestrial 